\title{
Meningkatkan Aktivitas dan Hasil Belajar PAI Dengan Menggunakan Metode Pembelajaran Teams Games Tournament (TGT) Siswa Kelas VII A SMP Negeri 1 Woha Semester Ganjil Tahun Pelajaran 2018/2019
}

\author{
Najamudin \\ SMPN 1 Woha \\ Email: najamudin_smp1woha72@gmail.com
}

\begin{abstract}
Abstrak. Strategi bermain aktif dengan model pembelajaran Teams Games Tournament (TGT) lebih menitikberatkan pada kegiatan berkompetisi antar kelompok siswa sehingga setiap siswa dituntut untuk dapat berjuang dengan baik agar kelompoknya dapat memenangkan pertandingan. Penelitian ini bertujuan untuk mengetahui apakah metode pembelajaran Teams Games Tournament (TGT) dapat meningkatkan aktivitas dan hasil belajar PAI siswa kelas VII A di SMPN 1 Woha Semester Ganjil Tahun Pelajaran 2018/2019, dan Seberapa besar peningkatan aktivitas dan hasil belajar PAI siswa kelas VII A dengan metode pembelajaran Teams Games Tournament (TGT) di SMPN 1 Woha Semester Ganjil Tahun Pelajaran 2018/2019. Jenis ini adalah Penelitian Tindakan Kelas (PTK), Desain Penelitian Tindakan Kelas yang digunakan sesuai dengan model PTK Kemmis dan McTaggart. Setiap siklus meliputi perencanaan (plan), tindakan (action), pengamatan (observation), evaluasi (evaluation) serta refleksi (reflection). Subyek dalam penelitian ini adalah siswa SMPN 1 Woha Tahun Pelajaran 2018/2019 sebanyak 30 orang. Instrumen yang digunakan dalam penelitian ini adalah soal tes dan lembar observasi. Berdasarkan analisis data yang telah dilakukan maka disimpulkan bahwa: (1) Metode pembelajaran Teams Games Tournament (TGT) dapat meningkatkan hasil belajar siswa. Hal ini dapat dibuktikan dari hasil tes belajar siswa dari siklus ke siklus II yang mengalami peningkatan. Pada siklus I persentase ketuntasan 46,67\% dengan nilai rata-rata 61,67. Pada siklus II mengalami peningkatan dengan persentase ketuntasan 76,67\%, nilai rata-rata 67,85. (2)Berdasarkan hasil observasi yang dilakukan, aktivitas guru pada siklus I tergolong cukup aktif dengan persentase 55\%. Pada siklus II mengalami peningkatan dengan persentase $80 \%$. (3) Hasil observasi aktivitas belajar siswa menunjukkan peningkatan. Pada siklus I keaktifan siswa tergolong cukup aktif dengan persentase 60\%. Pada siklus II mengalami peningkatan yang tergolong sangat aktif dengan persentase $90 \%$.
\end{abstract}

Keywords : Akvitas belajar, Hasil belajar, Teams Games tournament

\section{PENDAHULUAN}

Untuk mencapai keberhasilan kualitas belajar mengajar yang diharapkan perlu adanya suatu pendekatan yang relevan dengan tuntutan kurikulum yang terus berubah, sehingga apapun pendekatan yang digunakan dalam kegiatan belajar mengajar terutama dalam pembelajaran, sudah seharusnya siswa diposisikan sebagai pusat perhatian utama, agar siswa dapat aktif berpartisipasi dalam proses pembelajaran (Sudjana, 2006).

Proses pembelajaran suatu keberhasilan yang dapat dicapai siswa bukan hanya tergantung pada proses pembelajarannya, tetapi tergantung pula dari faktor itu sendiri. Sudjana (2006) mengemukakan hasil belajar yang dicapai siswa dipengaruhi oleh dua faktor, yaitu faktor dari dalam diri siswa dan faktor yang datang dari luar diri siswa atau lingkungan. Salah satu lingkungan belajar siswa yang dominan yang mempengaruhi hasil belajar di sekolah ialah kualitas belajar mengajar, sehingga untuk mencapai keberhasilan kualitas belajar mengajar yang diharapkan perlu adanya suatu pendekatan yang relevan dengan tuntutan kurikulum yag terus berubah. Apapun pendekatan yang digunakan dalam kegiatan belajar mengajar terutama dalam pembelajaran PAI sudah seharusnya siswa diposisikan sebagai pusat perhatian utama. Pola pembelajaran di kelas tidak hanya dilakukan dengan diktat, metode apa yang digunakan, melainkan juga bagaimana peran 
guru PAI memperkaya pengalaman belajar siswa. Pengalaman belajar bisa diperoleh melalui serangkaian penjelajahan lingkungan secara aktif.

SMP Negeri 1 Woha adalah salah satu sekolah dimana metode pembelajaran pada mata pelajaran PAI lebih banyak menggunakan metode ceramah, sehingga siswa kurang aktif berinteraksi ketika proses belajar mengajar. Hasil observasi peneliti dengan melihat nilai ketuntasan belajar siswa kelas VIIA SMPN 1 Woha diketahui jumlah ketuntasan klasikal mencapai 45\%. Masih jauh dibawah kriteria ketuntasan maksimal yaitu $75 \%$. Berdasarkan hasil identifikasi masalah diketahui bahwa siswa kelas VII A SMPN 1 Woha masih kurang aktif ketika proeses belajar mengajar berlangsung dan nilai ketuntasan belajarnya rendah, dikarenakan metode mengajar guru yang cenderung tidak menggunakan metode pembelajaran aktif sehingga peserta didik kurang antusias dalam proses belajar mengajar.

Pelaksanaan strategi bermain aktif dengan model pembelajaran Teams Games Tournament (TGT) yang dapat dikemas melalui kegiatan-kegiatan yang melibatkan aktivitas tubuh memungkinkan guru untuk menggunakan strategi bermain aktif dalam mengadakan pembelajaran PAI bagi anak usia sekolah menengah. Strategi bermain aktif diterapkan dengan merencanakan, menyusun, menyiapkan aktivitas bermain yang bervariasi yang melibatkan banyak aktivitas tubuh, dan kemudian melaksanakan kegiatan bermain yang dapat menumbuhkan kesenangan dan kepuasan pada diri peserta didik melalui aktivitas fisiknya.

Strategi bermain aktif dengan model pembelajaran Teams Games Tournament (TGT) lebih menitikberatkan pada kegiatan berkompetisi antar kelompok siswa sehingga setiap siswa dituntut untuk dapat berjuang dengan baik agar kelompoknya dapat memenangkan pertandingan. Adanya dimensi kegembiraan yang diperoleh dari penggunaan permainan dalam model pembelajaran kooperatif tipe TGT, diharapkan siswa dapat menikmati proses pembelajaran dengan situasi yang menyenangkan dan termotivasi untuk belajar dengan giat yang pada akhirnya akan mempengaruhi tingkat konsentrasi, kecepatan menyerap materi pelajaran, dan kematangan pemahaman terhadap sejumlah materi pelajaran sehingga hasil belajar mencapai optimal.

Atas dasar pemikiran inilah yang menggugah perhatian penulis untuk melakukan penelitian dalam menyusun penelitian tindakan kelas dengan mengangkat judul: Meningkatkan Aktivitas dan Hasil Belajar PAI Dengan Menggunakan Metode Pembelajaran Teams Games Tournament (TGT) Siswa Kelas VII A SMP Negeri 1 Woha Semester Ganjil Tahun Pelajaran 2018/2019.

\section{METODE \\ Jenis Penelitian}

Penelitian ini adalah Penelitian Tindakan Kelas (PTK). Penelitian tindakan kelas (PTK) harus tertuju atau mengenai halhal yang terjadi didalam kelas (Aqib, 2007) .

Desain Penelitian Tindakan Kelas yang digunakan sesuai dengan model PTK Kemmis dan McTaggart dalam Azmin (2019).

\section{Waktu dan Tempat Penelitian}

Penelitian ini dilaksanakan di SMPN 1 Woha, pada Semester Ganjil Tahun Pelajaran 2018/2019.

\section{Subyek Penelitian}

Subyek dalam penelitian ini adalah siswa SMPN 1 Woha Tahun Pelajaran 2018/2019 sebanyak 30 orang.

\section{Prosedur Penelitian}

Penelitian ini direncanakan dengan melewati beberapa siklus. Penelitian ini direncanakan dengan melewati beberapa siklus. Pada tiap siklus terdiri dari 4 tahapan, yaitu: 1) Perencanaan, 2) Pelaksanaan Tindakan, 3) Observasi, 4) Refleksi.

1. Perencanaan

Perencanaan merupakan perisiapan yang dilakukan sehubungan dengan pelaksanaan pembelajaran dengan metode Teams Games Tournament (TGT) untuk menyelesaikan masalah. Rencana kegiatan 
yang akan dilakukan pada tahap ini adalah:

a) Menyiapkan Rencana Pelaksanaan Pembelajaran (RPP) yang sesuai dengan standar kompetensi dan kompetensi dasar untuk mata pelajaran PAI kelas VII A materi Iman Kepada Allah.

b) Menyusun Lembar Kerja Siswa (LKS)

c) Menyusun format penilaian (unjuk kerja) dan observasi

d) Mengadakan tes awal

e) Membagi kelompok dan menjelaskan pembagian kelompok dan rencana pelaksanaan pembelajaran yang akan dilakukan.

2. Pelaksanaan Tindakan dan Pengamatan

a) Pendahuluan

1) Menyiapkan Rencana Pelaksanaan Pembelajaran (RPP)

2) Menyiapkan materi PAI tentang Iman Kepada Allah yang terangkum dalam modul pembelajaran

3) Membuat instrument penelitian

4) Melakukan pembagian kelompok

5) Membagi kelompok heterogen yang terdiri dari 3-5 siswa

6) Presentasi kelompok

b) Inti

Di dalam kelas siswa diharapkan dapat mengikuti proses pembelajaran dengan baik.

1) Mendengarkan saat guru sedang menerangkan materi pembelajaran

2) Menanyakan apa yang belum paham dari materi iman Kepada Allah yang disampaikan oleh guru.

3) Melaksanakan atau mengerjakan tugas yang diberikan oleh guru dengan penuh rasa tanggung jawab, cermat, dan tepat.

c) Penutup

1) Guru dengan siswa mengadakan refleksi terhadap proses dan hasil belajar

2) Guru memberi kesempatan siswa untuk bertanya. Apabila siswa merasa kurang paham atas materi yang disampaikan.

Pelaksanaan tindakan merupakan suatu kegiatan dilaksanakannya tahapan pembelajaran yang telah direncanakan.
Dalam hal ini sesuai dengan Rencana Pelaksanaan Pembelajaran (RPP) yang telah disiapkan.

\section{Refleksi}

Refleksi adalah kegiatan untuk mengemukakan kembali apa yang sudah terjadi (Arikunto, 2006:99). Kegiatan mengulas secara kritis tentang perubahan yang terjadi pada siswa, guru, dan suasana kelas. Berdasarkan hasil reflsksi ini, peneliti dapat melakukan revisi terhadap rencana kegiatan selanjutnya atau terhadap rencana siklus II. Pada tahap ini, peneliti menganalisis tes siklus I. Dari hasil tersebut nantinya akan dibandingkan dengan hasil tes siklus II. Masalah-masalah yang timbul pada siklus I akan dicarikan alternatif pemecahannya pada siklus II. Sedangkan kelebihannya akan dipertahankan dan diringkatkan lagi.

\section{Instrumen Penelitian}

Instrumen Instrument yang digunakan dalam penelitian ini terdiri dari:

1. Soal Tes

2. Lembar Observasi

\section{Teknik Analisis Data}

Analisis data menggunakan analisis deskriptif dan disajikan dalam persentase, Indikator keberhasilan Hasil belajar siswa dikatakan meningkat apabila tercapainya ketuntasan belajar secara klasikal yaitu $\geq 75 \%$ dan siswa memperoleh nilai ketuntasan individual $\geq 73$. Aktivitas guru dan siswa dikatakan meningkat apabila terjadinya peningkatan skor setiap siklusnya.

\section{HASIL DAN PEMBAHASAN \\ A. Hasil Penelitian \\ Kondisi Awal Siswa}

Kondisi awal siswa yaitu saat siswa belum menerima pembelajaran dengan metode pembelajaran Teams Games Tournament (TGT). Sebelum dilakukan penelitian tindakan kelas ini pembelajaran masih menggunakan metode pembelajaran yang kurang inovatif, yaitu pembelajaran masih berpusat pada guru sehingga aktivitas belajar siswa masih kurang optimal. Selain itu guru juga masih menggunakan media pendukung berupa buku paket PAI dalam menyampaikan materi sehingga hasil belajar 
siswa kurang optimal. Hal ini terlihat dari hasil belajar siswa yang masih rendah dan banyak yang belum tuntas dari kriteria ketuntasan minimal (KKM), yaitu sebesar $50 \%$. Dalam proses pembelajaran guru belum menggunakan metode pembelajaran inovatif sehingga siswa mudah bosan, kurang aktif, kurang berani mengemukakan pendapat, siswa juga kurang berani bertanya.

\section{Hasil Siklus I}

Siklus I merupakan langkah awal yang sangat menentukan siklus berikutnya, karena dalam siklus ini terdapat usaha pembenahan dalam proses interaksi antara siswa dan guru dalam pembelajaran. Pada siklus ini pembelajaran dilaksanakan dengan satu kali pertemuan dengan alokasi waktu 2 x 45 menit menggunakan metode pembelajaran Teams Games Tournament (TGT). Pelaksanaan siklus I dilaksanakan dengan beberapa tahap, yaitu:

a) Perencanaan

Pada tahap perencanaan dilakukan kegiatan mempersiapkan rencana pelaksanaan pembelajaran, menyiapkan lembar observasi untuk mencatat aktivitas siswa dalam pembelajaran, lembar kerja siswa, dan menyiapkan soal evaluasi untuk mengetahui ketuntasan belajar siswa. Guru juga mengupayakan agar kondisi kelas kondusif sehingga proses pembelajaran dapat berjalan dengan baik, lancar, dan baik sesuai dengan rencana pelaksanaan pembelajaran.

b) Pelaksanaan Tindakan

Pelaksanaan tindakan dilakukan sesuai dengan rencana yang telah direncanakan pada tindakan perencanaan di atas. Dalam tahap pelaksanaan tindakan ini peneliti melaksanakan pembelajaran tatap. Pertama kali yang dilakukan dalam tindakan pada siklus I ini adalah: setelah guru masuk ke dalam kelas, guru menyampaikan tujuan pembelajaran, kemudian guru menginformasikan model pembelajaran yang digunakan yaitu menggunakan metode pembelajaran Teams Games Tournament (TGT). Setelah itu maka guru memotivasi siswa (memfokuskan siswa) dengan cara tanya jawab masalah kehidupan sehari-hari. Siswa diingatkan kembali tentang materi pelajaran. Kemudian Guru membagi siswa dalam kelompok heterogen yang beranggotakan 3-5 orang siswa dan menetapkan satu siswa sebagai ketua kelompok dan membagikan lembar kerja siswa yang berisikan permasalahan yang berkaitan dengan iman kepada Allah untuk didiskusikan secara berkelompok (menciptakan masyarakat belajar), guru menyiampaikan pelajaran, dan kemudian kelompok belajar dalam tim mengerjakan lembar kegiatan untuk menguasai materi, para siswa memainkan game turnamen dalam kemampuan yang homogeny, memberi penghargaan kepada kelompok yang mencapai skor dengan kriteria tertentu, siswa mengerjakan kuis individual untuk mengetahui tingkat keberhasilan siswa.

c) Pengamatan

Hasil pengamatan siklus I dicatat dalam lemabar observasi yang telah dipersiapkan. Pengamatan siklus I diperoleh hasil sebagai berikut:

a. Hasil observasi siswa siklus I

Hasil pengamatan siklus I menunjukkan bahwa 60\% siswa cukup aktif dalam pembelajaran dengan menggunakan metode metode pembelajaran Teams Games Tournament (TGT).

b. Hasil observasi aktivitas guru siklus I

Hasil pengamatan aktivitas guru pada siklus I menunjukkan bahwa $55 \%$ dalam pembelajaran dengan menggunakan metode metode pembelajaran Teams Games Tournament (TGT).

d) Refleksi

Berdasarkan hasil pengamatan pada siklus I baik guru maupun siswa masih kurang maksimal dalam proses pembelajaran. Adapun yang menjadi kendalanya sebagai berikut:

a. Hasil observasi aktivitas guru mencapai 55\%. Hal ini menunjukkan bahwa guru masih kurang maksimal 
dalam proses pembelajaran dengan metode pembelajaran Teams Games Tournament (TGT).

b. Hasil observasi aktivitas belajar siswa mencapai $60 \%$. Hal ini menunjukkan siswa masih kurang maksimal dalam pembelajaran

c. Guru kurang maksimal dalam memotivasi siswa

d. Guru kurang maksimal dalam pengelolaan waktu sehingga siswa kurang aktif selama proses pembelajaran berlangsung

e. Siswa belum terbiasa dengan metode pembelajaran Teams Games Tournament (TGT).

Hasil evaluasi pembelajaran pembelajaran pada siklus I dengan metode pembelajaran Teams Games Tournament (TGT) mencapai mencapai 46,67\%. Hasil tersebut menunjukkan bahwa pada siklus pertama secara klasikal siswa belum tuntas belajar lebih kecil dari persentase ketuntasan yang dikehendaki yaitu sebesar $75 \%$

\section{Hasil Siklus II}

Melihat hasil siklus I yang kurang maksimal dalam pemelajaran PAI, maka guna memaksimalkan hasil yang diingin dicapai maka dilakukan siklus lanjutan. Siklus lanjutan ini juga terdiri dari tindakan perencanaan, pelaksanaan tindakan, observasi dan refleksi.

\section{a) Perencanaan}

Perencanaan tindakan pada siklus II ini dilakukan tidak jauh beda dengan siklus I yaitu dengan membuat Rencana Pembelajaran (RP), membuat Lembar Kegiatan Siswa (LKS) dan membuat beberapa soal uji kompetensi siklus II, membuat Lembar Pengamatan Aktivitas Siswa dalam KBM dan Lembar Pengamatan Tinjauan Kelas. Tidak lupa dalam akhir kegiatan selalu dilakukan suatu evaluasi guna mengetahui peningkatan dan perubahan yang dialami oleh siswa selama proses pembelajaran.

b) Pelaksanaan

Pelaksanaan tindakan yang dilakukan pada siklus II ini, dilakukan dengan melihat hasil pada siklus I di atas, dengan melihat kekurangan yang ada, maka pada siklus II ini dilakukan langkah-langkah perbaikan. Tindakan yang dilakukan pada siklus II ini meliputi: Tindakan siklus II dilaksanakan dalam 1 kali pertemuan dengan alokasi waktu 2 x 45 menit dengan tahapan: Setelah guru memasuki ruang maka guru/peneliti menyampaikan tujuan pembelajaran, setelah itu guru mulai membagi siswa dalam kelompok-kelompok yang heterogen yang terdiri atas 3-5 siswa dan menetapkan satu siswa sebagai ketua kelompok dan membagikan lembar kerja siswa yang berisikan permasalahan yang berkaitan dengan iman kepada Allah untuk didiskusikan secara berkelompok (menciptakan masyarakat belajar), kemudian kelompok belajar dalam tim mengerjakan lembar kegiatan untuk menguasai materi, para siswa memainkan game turnamen dalam kemampuan yang homogeny, memberi penghargaan kepada kelompok yang mencapai skor dengan kriteria tertentu, siswa mengerjakan kuis individual untuk mengetahui tingkat keberhasilan siswa. Kemudian guru mengadakan tes kepada para siswa guna mengetahui peningkatan yang diperoleh siswa dalam memahami pelajaran PAI materi iman Kepada Allah.

c) Pengamatan

Hasil pengamatan siklus I dicatat dalam lemabar observasi yang telah dipersiapkan. Pengamatan siklus I diperoleh hasil sebagai berikut:

1. Hasil observasi siswa siklus I

Hasil pengamatan siklus I menunjukkan bahwa $90 \%$ siswa aktif dalam pembelajaran dengan menggunakan metode metode pembelajaran Teams Games Tournament (TGT).

2. Hasil observasi aktivitas guru siklus I

Hasil pengamatan aktivitas guru pada siklus I menunjukkan bahwa $80 \%$ dalam pembelajaran dengan menggunakan metode metode pembelajaran Teams Games Tournament (TGT).

d) Reflksi

Berdasarkan hasil pengamatan pada siklus II baik guru maupun siswa sudah mengalami peningkatan dalam proses pembelajaran. Adapun hasil 
persentasenya sebagai berikut:

1. Hasil observasi aktivitas guru mencapai $80 \%$. Hal ini menunjukkan bahwa guru sudah mulai aktif dan maksimal dalam proses pembelajaran dengan metode pembelajaran Teams Games Tournament (TGT).

2. Hasil observasi aktivitas belajar siswa mencapai 90\%. Hal ini menunjukkan siswa sudah mulai aktif dan maksimal dalam pembelajaran

3. Aktivitas guru dalam pembelajaran sudah memenuhi kriteria

4. Kemampuan guru dalam mengeloal kelas juga baik

5. Siswa sangat antusias dalam proses pembelajaran

6. Siswa semaki baik dalam bertanya, dan mengemukakan pendapatnya

Hasil evaluasi pembelajaran pembelajaran pada siklus II dengan metode pembelajaran Teams Games Tournament (TGT) mengalami peningkatan dengan persentase ketuntasan kelasikal mencapai mencapai $76,67 \%$ dengan nilai rata-rata 67,83. Hasil tersebut menunjukkan bahwa pada siklus II ini secara klasikal siswa sudah tuntas dari persentase ketuntasan yang dikehendaki yaitu sebesar $75 \%$. Adanya peningkatan hasil belajar siswa ini karena siswa sudah mulai akrab dan menemuan keasyikan dengan metode pembelajaran Teams Games Tournament (TGT). Disamping itu kemampuan guru dalam mengelola proses belajar mengajar dalam metode ini juga semakin meningkat sehingga proses belalarmengajar semakin efektif

\section{B. PEMBAHASAN}

Berdasarkan tes hasil belajar yang dilakukan tiap pembelajaran atau persiklusnya diketahui bahwa siswa semakin aktif pada pertemuan berikutnya meskipun pada pertemuan pertama hasilnya kurang dari harapan. Hal ini ditandai dengan semakin meningkatnya jumlah ketuntasan. Pada siklus I persentase ketuntasan 46,67\% dengan nilai rata-rata 61,67. Pada siklus II persentase ketuntasan $76,67 \%$ dengan nilai rata-rata 67,85 . Pada tahap ini siswa sudah aktif dalam proses belajar mengajar dan siswa sudah memahami materi yang diajarkan pada materi sebelumnya.

Berdasarkan hasil observasi yang dilakukan, aktivitas guru pada siklus I tergolong cukup aktif dengan persentase 55\% dikarenakan kurangnya introduksi antara guru dengan siswa dan kurangnya motivasi pada siswa. Sedangkan pada siklus II tergolong aktif dengan persentase $80 \%$ disebabkan guru sudah mampu memotivasi siswa agar tidak malu mengungkapkan pendapat dan pertanyaan kepada guru mengenai hal-hal yang belum dimengerti. Jadi pada siklus II terjadi peningkatan, karena guru sudah memperbaiki kekurangan pada siklus I.

Berdasarkan hasil observasi aktivitas belajar siswa menunjukkan peningkatan. Pada siklus I keaktifan siswa tergolong cukup aktif dengan persentase $60 \%$ karena siswa masih terpengaruh terhadap situasi di luar kelas dan tidak berusaha menjawab pertanyaan yang diberikan oleh guru. Sedangkan pada siklus II mengalami peningkatan yang tergolong sangat aktif dengan persentase $90 \%$ dikarenakan siswa telah memperbaiki kesalahan pada siklus I diantaranya tidak terpengaruh terhadap situasi di luar kelas dan berusaha menjawab pertanyaan yang diberikan oleh guru serta bertanya apabila mengalami kesulitan.

Peningkatan keaktifan siswa yang dicapai didukung oleh meningkatnya keaktifan guru. Hal ini dibuktikan dengan hasil observasi aktivitas belajar, dimana keaktifan guru pada siklus I sebesar 55\% pada siklus II meningkat menjadi $80 \%$. Hasil observasi aktivitas siswa pada siklus I sebesar $60 \%$ pada siklus II meningkat menjadi $90 \%$.

Peningkatan hasil dan aktivitas belajar merupakan tolak ukur untuk mengetahui tingkat keberhasilan siswa dalam proses belajar mengajar. Proses belajar mengajar dikatakan baik, bila proses tersebut dapat membangkitkan kegiatan belajar yang efektif. Jika dilihat dari hasil belajar yang diperoleh siswa persiklus mengalami peningkatan. Peningkatan hasil belajar dikarenakan adanya peningkatan aktivitas guru dan siswa pada siklus I dan II, artinya proses pembelajaran dengan metode pembelajaran Teams Games Tournament (TGT) mengalami perbaikan. 
Dengan kata lain bahwa proses pembelajaran dengan metode metode pembelajaran Teams Games Tournament (TGT) dapat meningkatan keaktifan dan hasil belajar siswa.

Hasil refleksi siklus I mengisyaratkan perbaikan-perbaikan tindaakan selanjutnya, adapun tindakan yang dilakukan untuk memperbaiki kekurangan dan kelemahan siklus I antara lain guru harus lebih mengaktifkan siswa terutama dalam bertanya dan diskusi serta guru juga harus benar-benar membimbing kelompok atau siswa yang mengalami kesulitan dalam menyelesaikan soal-soal secara merata tanpa memandang yang pintar dan yang bodoh. Meningkatkannya penguasaan kosakata bahasa Inggris tersebut tidak terlepas dari penggunaan model pembelajaran Teams Games Tournament (TGT). Model pembelajaran Teams Games Tournament (TGT) mudah diterapkan, melibatkan aktivitas seluruh siswa tanpa harus ada perbedaan status, melibatkan peran siswa sebagai tutor sebaya dan mengandung unsur permainan dan reinforcement. Sementara itu, cooperative learning, menurut Santyasa (2009:30) adalah "suatu strategi pembelajaran yang terstruktur dan sistematis, di mana kelompok-kelompok kecil bekerja sama untuk mencapai tujuantujuan bersama". Pada model ini siswa dituntut aktif dan bertanggung jawab atas hasil pembelajarannya, sedangkan guru lebih berperan sebagai fasilitator yang berfungsi sebagai jembatan penghubung ke arah pemahaman yang lebih tinggi.

\section{KESIMPULAN}

Berdasarkan hasil pembahasan diatas dapat disimpulkan bahwa:

1. Metode pembelajaran Teams Games Tournament (TGT) dapat meningkatkan hasil belajar siswa. Hal ini dapat dibuktikan dari hasil tes belajar siswa dari siklus ke siklus II yang mengalami peningkatan. Pada siklus I persentase ketuntasan $46,67 \%$ dengan nilai rata-rata 61,67. Pada siklus II mengalami peningkatan dengan persentase ketuntasan $76,67 \%$, nilai rata-rata 67,85 .
2. Berdasarkan hasil observasi yang dilakukan, aktivitas guru pada siklus I tergolong cukup aktif dengan persentase 55\%. Pada siklus II mengalami peningkatan dengan persentase $80 \%$.

3. Hasil observasi aktivitas belajar siswa menunjukkan peningkatan. Pada siklus I keaktifan siswa tergolong cukup aktif dengan persentase $60 \%$. Pada siklus II mengalami peningkatan yang tergolong sangat aktif dengan persentase $90 \%$.

\section{DAFTAR PUSTAKA}

Aqib, 2007. Melaksanakan Penelitian Tindakan Kelas (PTK) Itu Mudah. Jakarta: Bumi Aksara.

Arikunto. S. 2006. Prosedur Penilitian Suatu Pendekatan Praktek. Jakarta:Renika Cipta.

Santyasa, I W. 2009. Materi Pendidikan dan Latihan Profesi Guru (PLPG); Modelmodel Pembelajaran Inovatif. Singaraja: Universitas Pendidikan Ganesha

Slavin, Robert E. 2009. Cooperative Learning Teori, Riset, dan Praktik. Bandung: Nusa Media

Soemanto,Wasty. $2007 . \quad$ Psikologi Pendidikan. Jakarta: Rineka Cipta

Sudjana. 2006. Keaktifan Siswa. Bandung. Alfabeta. 